\title{
Plants traditionally used against malaria: phytochemical and pharmacological investigation of Momordica foetida
}

\author{
Sonja Froelich ${ }^{1}$, Bernadina Onegi ${ }^{2}$, Adrian Kakooko ${ }^{2}$, Karsten Siems ${ }^{3}$, Carola Schubert ${ }^{1}$, \\ Kristina Jenett-Siems ${ }^{1 *}$
}

\author{
${ }^{1}$ Institut für Pharmazie (Pharmazeutische Biologie), Freie Universität Berlin, Königin-Luise \\ Str. 2+4, D-14195, Berlin, Germany, \\ ${ }^{2}$ Department of Pharmacy (Pharmacognosy Unit), Makerere University, Kampala, Uganda, \\ ${ }^{3}$ Analyticon Discovery GmbH, Hermannswerder Haus 17, D-14473, Potsdam, Germany
}

\begin{abstract}
RESUMO: "Plantas tradicionalmente utilizadas contra malária: investigação fitoquímica e farmacológica de Momordica foetida". Folhas de Momordica foetida tradicionalmente usadas para tratar sintomas de malária em partes da África Oriental foram estudadas in vitro com respeito à sua atividade antimalárica. Utilizando-se o teste de incorporação de hipoxantina $\left[{ }^{3} \mathrm{H}\right]$ a atividade antiplasmódica dos extratos hidrofílico e lipofílico contra a cepa sensíveis a cloroquina poW e o clone multiresistente Dd2 de Plasmodium falciparum foi determinada. O extrato éter de petróleo/ acetato de etila mostrou atividade significativa com valores de $\mathrm{CI}_{50}$ de $7,3 \mu \mathrm{g} / \mathrm{mL}$ (poW) e 13,0 $\mu \mathrm{g} / \mathrm{mL}$ (Dd2). A citotoxicidade foi estimada em duas linhas de células humanas HepG2 e ECV304 e o índice de seletividade (IS) foi calculado, variando entre 12 e 15. A análise fitoquímica levou ao isolamento de um número de glicosídeos fenólicos, por exemplo eriodictiol-, 5,7,4'triidroxiflavanona, kaempferol e 5,7-diidroxicromona-7-O- $\beta$-D-glicopiranosideo, descritos pela primeira vez de $M$. foetida. Na tentativa de provar um possível modo de ação foi avaliada a influência dos extratos brutos bem como dos compostos isolados sobre a degradação da heme usando-se cloroquina como composto de referência. O extrato acetato de etila mostrou inibição da degradação da heme em torno de $88 \%$, bastante similar a cloroquina (84\%) e também o eriodictiol7-O- $\beta$-D-glicopiranosideo (2) inibiu a degradação da heme em $86 \%$.
\end{abstract}

Unitermos: Momordica foetida, Cucurbitaceae, glicosídeos de flavonóides, teste de GSH-haemin, malária, medicina tradicional.

\begin{abstract}
Leaves from Momordica foetida traditionally used to treat symptoms of malaria in parts of East Africa were studied for in vitro antimalarial activity. Using an $\left[{ }^{3} \mathrm{H}\right]$ hypoxanthineincorporation assay the antiplasmodial activity of hydrophilic and lipophilic extracts against the chloroquine-sensitive strain poW and the multiresistant clone Dd2 of Plasmodium falciparum was determined. The petrol ether/ethyl acetate extract showed significant activity with $\mathrm{IC}_{50}$ values of $7.3 \mu \mathrm{g} / \mathrm{mL}$ (poW) and $13.0 \mu \mathrm{g} / \mathrm{mL}$ (Dd2). Cytotoxicity was estimated on two human cell lines HepG2 and ECV-304 and a selectivity index (SI) was calculated, ranging between 12 and 15. Phytochemical analysis led to the isolation of a number of phenolic glycosides, e.g. eriodictyol-, 5,7,4'-trihydroxyflavanone-, kaempferol- and 5,7-dihydroxychromone-7-O- $\beta$-D-glucopyranoside, not previously known from $M$. foetida. In order to prove one possible mode of action the influence of the crude extracts as well as the isolated compounds on the heme degradation with chloroquine as reference compound was evaluated. The ethyl acetate extract showed about $88 \%$ inhibition of heme degradation, quite similar to chloroquine $(84 \%)$, and also eriodictyol-7-O- $\beta$-D-glucopyranoside (2) inhibited heme degradation by $86 \%$.
\end{abstract}

Keywords: Momordica foetida, Cucurbitaceae, flavonoid glycosides, GSH-haemin multiwell assay, malaria, traditional medicine.

\section{INTRODUCTION}

Momordica foetida Schumach. \& Thonn. is a perennial climbing herb with tendrils, the flowers are cream often with a reddish or orange centre. Male and female flowers are found on the same plant. The characteristic fruit is bright orange with prickles. This species with its beautiful habit but a strong and unpleasant smell belongs to the Cucurbitaceae family.
The Cucurbitaceae consist of about 120 genera and 850 species that are widely distributed (Jeffrey, 1990). Many species are commercially grown for their nutritive value and in some cases they are used for medicinal purposes. In East and Central Africa, M. foetida is used to treat a number of ailments which include hypertension, diabetes mellitus, fever and especially symptoms of malaria (Hakizamungu et al., 1992; Rwangabo, 1993).

Previous phytochemical studies resulted in the 
isolation of cucurbitane triterpenoids from a leaf extract (Mulholland, 1997), alkaloids and glycosides from the complete plant (Olaniyi; Marquis, 1975; Olaniyi, 1975) and the identification of sitosteryl glycoside, 5,25stigmastadien-3ß-yl-glucoside and 1ß-hydroxyfriedel6-en-3-one (Olaniyi, 1980). In vivo studies with water extracts showed that $M$. foetida orally given in different doses prolonged the survival of Plasmodium berghei infected mice (Waako et al., 2005). In this study, we have examined the antiplasmodial activity, cytotoxicity and effects on the GSH-dependent heme degradation of crude plant extracts and isolated compounds from M. foetida.

\section{MATERIAL AND METHODS}

\section{Spectrometric methods}

${ }^{1} \mathrm{H}$ NMR spectra were recorded on a Bruker AVANCE DPX 400-spectrometer (400 MHz) using TMS as internal standard. Samples were dissolved in acetone$\mathrm{d}_{6}$, chloroform- $\mathrm{d}_{1}$ or methanol- $\mathrm{d}_{4}$. FAB-MS were obtained on a Varian MAT $\mathrm{CH}_{5} \mathrm{DF}$ instrument with DMSO/ Glycerin, Xenon; $\mathrm{CHCl}_{3} /$ slm-Nitrobenzylalkohol, Xenon or $\mathrm{MeOH} /$ Glycerin, Xenon as solvents. EI-MS were recorded on a Varian $\mathrm{MAT} \mathrm{CH}_{7} \mathrm{~A},(70 \mathrm{eV})$.

\section{Plant material}

M. foetida was collected in Kisaasi, a place 10 $\mathrm{km}$ north of Kampala. It was identified by Mr. Adrian Kakooko, the botanist and plant taxonomist from the Makerere University, Kampala, Uganda. The general habitat range is in clearings and along forest edges. Voucher specimens are deposited in the herbarium of the Department of Pharmacy, Makerere University, Kampala, Uganda.

\section{Extraction and isolation of compounds}

Air dried leaves (345 g) were extracted with methanol $(3 \times 1.5 \mathrm{~L})$. The extract was concentrated under reduced pressure yielding $52.2 \mathrm{~g}$ of the crude methanol extract (CME). The dry CME was acidified with a $2 \%$ $(\mathrm{m} / \mathrm{v})$ aqueous solution of tartaric acid. The aqueous layer was extracted with petrol ether $(3 \times 0.30 \mathrm{~L}), \mathrm{CH}_{2} \mathrm{Cl}_{2}(3 \mathrm{x}$ $0.30 \mathrm{~L})$, EtOAc $(3 \times 0.30 \mathrm{~L})$ and butanol $(3 \times 0.30 \mathrm{~L})$. The evaporated EtOAc-extract $(2.0 \mathrm{~g})$ was dissolved in $5 \mathrm{~mL}$ methanol, and subjected to chromatography on a glass column $(2.5 \times 34 \mathrm{~cm})$ packed with Sephadex LH 20 (40 g) and eluted with $0.25 \mathrm{~L}$ methanol to give 50 fractions. From fractions 13-17 compound 1 (4 mg) crystallized spontaneously. From fractions 11-12 compound $\mathbf{3}$ was isolated by preparative TLC $\left(\mathrm{HCO}_{2} \mathrm{H}_{-} \mathrm{H}_{2} \mathrm{O}-\mathrm{EtOAc}\right.$ 9:9:82, $\mathrm{R}_{\mathrm{f}} 0.49,7 \mathrm{mg}$ ).

Fractions 18-24 yielded three compounds $2\left(\mathrm{R}_{\mathrm{t}}\right.$ $=370 \mathrm{~s}, 2.6 \mathrm{mg}), 4\left(\mathrm{R}_{\mathrm{t}}=723 \mathrm{~s}, 4.1 \mathrm{mg}\right)$ and again $\mathbf{1}\left(\mathrm{R}_{\mathrm{t}}\right.$ $=492 \mathrm{~s}, 4.2 \mathrm{mg})$ upon preparative HPLC $\left(\mathrm{H}_{2} \mathrm{O}-\mathrm{MeOH}\right.$
70:30, after $20 \min$ 30:70, after $30 \min$ 1:99 $\mathrm{MeOH}$ ).

The $\mathrm{CH}_{2} \mathrm{Cl}_{2}$-extract $(0.29 \mathrm{~g})$ was subjected to column chromatography on LiChroprep ${ }^{\circledR} \mathrm{RP}-18$ material [Merck, 40-63 $\mu \mathrm{m}$ ] ( $\mathrm{H}_{2} \mathrm{O}-\mathrm{MeOH} 60: 40$ to $\left.\mathrm{MeOH}\right)$ yielding 123 fractions. From fractions 5-14 crystals were obtained, which were further purified by preparative TLC $\left(\mathrm{CHCl}_{3}\right.$-EtOAc $\left.60: 40\right)$ to give compound $5\left(\mathrm{R}_{\mathrm{f}} 0.6,12.6\right.$ $\mathrm{mg})$.

Fractions 15-64 were purified by preparative TLC (cyclohexane-EtOAc 50:50) and compound $6\left(\mathrm{R}_{\mathrm{f}}\right.$ $0.06,5 \mathrm{mg}$ ) was obtained.

\section{Chromatographic system}

Analyses were carried out on a Knauer HPLC Pump 64 apparatus, Knauer HPLC Programmer 50, barspec Chrom-A-Scope Detector (Knauer, Berlin, Germany).

A reversed phase mode column Eurospher 100 C18 (250 x $4.0 \mathrm{~mm}$ I.D., $5 \mu \mathrm{m}$ ) was employed (Knauer, Berlin, Germany) at room temperature of $25^{\circ} \mathrm{C}$, flow rate of $1.5 \mathrm{~mL} / \mathrm{min}$ and wavelength of $225 \mathrm{~nm}$. Solvents used were of HPLC grade (LGC Promochem, Wesel, Germany) and were degassed by sonication before use.

5, 7, 4'-Trihydroxyflavanone-7-O- $\beta$-Dglucopyranoside (Prunin) (1): (-) FAB-MS m/z 433 [M$\mathrm{H}] ;{ }^{1} \mathrm{H}$ NMR (Acetone-d, $\left.400 \mathrm{MHz}\right): \delta 2.77(1 \mathrm{H}, d d, J=$ $3.0 \mathrm{~Hz}, J=17.0 \mathrm{~Hz}, \mathrm{H}-3 e q), 3.23(1 \mathrm{H}, d d, J=13.0 \mathrm{~Hz}, J$ $=17.0 \mathrm{~Hz}, \mathrm{H}-3 \mathrm{ax}), 3.47$ (2H, $t, J=8.8 \mathrm{~Hz}, \mathrm{H}-2$ ", H-3"), 3.56 (1H, $t, J=8.8 \mathrm{~Hz}, \mathrm{H}-4$ "), 3.60 (1H, $m, \mathrm{H}-5$ "), 3.70 $(1 \mathrm{H}, d d, J=5.3 \mathrm{~Hz}, J=11.8 \mathrm{~Hz}, \mathrm{H}-6$ "a), 3.88 (1H, $d d$, $J=2.34 \mathrm{~Hz}, J=11.8 \mathrm{~Hz}, \mathrm{H}-6$ " b ), 5.07 (1H, $d, J=7.4$ Hz, H-1"), 5.49 (1H, dd, $J=3.0 \mathrm{~Hz}, J=13.0 \mathrm{~Hz}, \mathrm{H}-2 a x)$, $6.14(1 \mathrm{H}, d, J=2.2 \mathrm{~Hz}, \mathrm{H}-6), 6.17(1 \mathrm{H}, d, J=2.2 \mathrm{~Hz}, \mathrm{H}-$ 8), $6.90(2 \mathrm{H}, d, J=8.6 \mathrm{~Hz}, \mathrm{H}-3$ ',H-5'), 7.38 (2H, $d, J=$ $8.6 \mathrm{~Hz}, \mathrm{H}-2$ ', H-6'), 12.07 (1H, s, 5-OH).

$5,7,3$ ', 4'-Tetrahydroxyflavanone-7-O- $\beta-D$ glucopyranoside (Eriodictyol-7-O- $\beta$-D-glucopyranoside) (2): (-) FAB-MS $m / z 449$ [M-H]; ' ${ }^{1} \mathrm{H}$ NMR (Acetone-d, $400 \mathrm{MHz}): \delta 2.77(1 \mathrm{H}, d d, J=3.0 \mathrm{~Hz}, J=17.1 \mathrm{~Hz}, \mathrm{H}-$ $3 e q), 3.20(1 \mathrm{H}, d d, J=12.6 \mathrm{~Hz}, J=17.1 \mathrm{~Hz}, \mathrm{H}-3 a x), 3.47$ $(2 \mathrm{H}, t, J=9.3 \mathrm{~Hz}, \mathrm{H}-2$ ", H-3"), $3.53(1 \mathrm{H}, t, J=8.9 \mathrm{~Hz}$, H-4"), 3.61 (1H, $m, \mathrm{H}-5$ "), $3.70(1 \mathrm{H}, d d, J=5.4 \mathrm{~Hz}, J=$ $11.9 \mathrm{~Hz}, \mathrm{H}-6$ "a), $3.89(1 \mathrm{H}, d d, J=2.9 \mathrm{~Hz}, J=11.9 \mathrm{~Hz}$, H-6”b), $5.08(1 \mathrm{H}, d, 7.6 \mathrm{~Hz}, \mathrm{H}-1$ ") $), 5.44(1 \mathrm{H}, d d, J=3.0$ $\mathrm{Hz}, J=12.6 \mathrm{~Hz}, \mathrm{H}-2 a x), 6.13(1 \mathrm{H}, d, J=2.0 \mathrm{~Hz}, \mathrm{H}-8)$, $6.16(1 \mathrm{H}, d, J=2.0 \mathrm{~Hz}, \mathrm{H}-6), 6.88(2 \mathrm{H}, s, \mathrm{H}-2$ ', H-5'), 7.04 (1H, s, H-6'), 12.07 (1H, s, 5-OH).

5, 7 -Dihydroxychromone- $7-O-\beta-D-$ glucopyranoside (3): (+) FAB-MS $m / z 363[\mathrm{M}+\mathrm{Na}]^{+} ;{ }^{1} \mathrm{H}$ NMR (Acetone-d , $400 \mathrm{MHz}$ ): $\delta 3.42-3.62(4 \mathrm{H}, m, \mathrm{H}-2$ ", H-3", H-4", H-5"), $3.71(1 \mathrm{H}, d d, J=5.5 \mathrm{~Hz}, J=11.5 \mathrm{~Hz}$, H-6"a), 3.91 (1H, dd, $J=2.0 \mathrm{~Hz}, J=11.5 \mathrm{~Hz}, \mathrm{H}-6$ "'b), $5.13(1 \mathrm{H}, d, J=7.5 \mathrm{~Hz}, \mathrm{H}-1$ '), $6.28(1 \mathrm{H}, d, J=6.0 \mathrm{~Hz}$, $\mathrm{H}-3), 6.45(1 \mathrm{H}, d, J=2.2 \mathrm{~Hz}, \mathrm{H}-6), 6.66(1 \mathrm{H}, d, J=2.2$ $\mathrm{Hz}, \mathrm{H}-8), 8.14(1 \mathrm{H}, d, J=6.0 \mathrm{~Hz}, \mathrm{H}-2), 12.72(1 \mathrm{H}, s$, $5-\mathrm{OH})$. 
Kaempferol-7-O- $\beta$-D-glucopyranoside (Populnin) (4): (-) FAB-MS $m / z 447$ [M-H] ; ${ }^{1} \mathrm{H}$ NMR (Acetone-d $\left.{ }_{6}, 400 \mathrm{MHz}\right): \delta 3.28(1 \mathrm{H}, \mathrm{m}, \mathrm{H}-5$ "), $3.36(1 \mathrm{H}$, $t, J=8.5 \mathrm{~Hz}, \mathrm{H}-2 "), 3.45$ (2H, $m, \mathrm{H}-3$ ", H-4"), 3.51 (1H, $d d, J=5.5 \mathrm{~Hz}, J=11.5 \mathrm{~Hz}, \mathrm{H}-6$ "a), $3.64(1 \mathrm{H}, d d, J=3.0$ $\mathrm{Hz}, J=11.5 \mathrm{~Hz}, \mathrm{H}-6$ "b), $5.26(1 \mathrm{H}, d, J=7.5 \mathrm{~Hz}, \mathrm{H}-1$ "), $6.29(1 \mathrm{H}, d, J=1.9 \mathrm{~Hz}, \mathrm{H}-6), 6.53(1 \mathrm{H}, d, J=1.9 \mathrm{~Hz}, \mathrm{H}-$ 8), $6.98(2 \mathrm{H}, d, J=8.9 \mathrm{~Hz}, \mathrm{H}-3$ ', $\mathrm{H}-5$ '), 8.15 (2H, $d, J=$ $8.9 \mathrm{~Hz}, \mathrm{H}-2$ ', H-6'), 12.44 (1H, $s, 5-\mathrm{OH})$.

5,7-Dihydroxychromone (5): EI-MS $m / z$ (rel. int. \%) $178[\mathrm{M}]^{+}$(100), 150 [M-CO] (35), 124 (26), 111 (14), 97 (22). ${ }^{1} \mathrm{H}$ NMR (Methanol-d $\left.{ }_{4}, 400 \mathrm{MHz}\right): \delta 6.14(1 \mathrm{H}, d$, $J=6.0 \mathrm{~Hz}, \mathrm{H}-3), 6.15(1 \mathrm{H}, d, J=2.0 \mathrm{~Hz}, \mathrm{H}-8), 6.27(1 \mathrm{H}$, $d, J=2.0 \mathrm{~Hz}, \mathrm{H}-6), 7.93(1 \mathrm{H}, d, J=6.0 \mathrm{~Hz}, \mathrm{H}-2)$.

2-Hydroxybenzoic acid (Salicylic acid) (6): EIMS $m / z$ (rel. int. \%) $138[\mathrm{M}]^{+}$(54), $120\left[\mathrm{M}-\mathrm{H}_{2} \mathrm{O}\right](100)$, 92 (53), 64 (19), 39 (16). ${ }^{1} \mathrm{H}$ NMR ( $\left.\mathrm{CDCl}_{3}, 400 \mathrm{MHz}\right): \delta$ $6.90(1 \mathrm{H}, d t, 0.5 \mathrm{~Hz}, 8.0 \mathrm{~Hz}, \mathrm{H}-4 / \mathrm{H}-5), 7.0(1 \mathrm{H}, d d, 0.5$ $\mathrm{Hz}, 8.0 \mathrm{~Hz}, \mathrm{H}-3), 7.48(1 \mathrm{H}, d t, 0.5 \mathrm{~Hz}, 8.0 \mathrm{~Hz}, \mathrm{H}-4 / \mathrm{H}-$ 5), $7.90(1 \mathrm{H}, d d, 0.5 \mathrm{~Hz}, 8.0 \mathrm{~Hz}, \mathrm{H}-6), 10.62(1 \mathrm{H}, b r s$, $-\mathrm{COOH})$.

\section{Materials}

RPMI 1640 medium was purchased from Gibco-BRL. GSH and diethylenetriamine-penta-acetic acid (DETEPAC) were obtained from Lancaster. Haemin, HEPES, Na phosphates, $\mathrm{NaHCO}_{3}$ and DMSO were obtained from Roth. $\left[{ }^{3} \mathrm{H}\right]$ Hypoxanthine was purchased from Amersham. Flat-bottomed 96-well plates were obtained from Neolab.

\section{In vitro antiplasmodial activity}

The chloroquine-sensitive strain of $P$. falciparum poW $\left(\mathrm{IC}_{50}\right.$ of chloroquine $\left.=0.011 \mu \mathrm{M}\right)$ and a chloroquineresistant clone $\mathrm{Dd} 2\left(\mathrm{IC}_{50}\right.$ of chloroquine $\left.=0.12 \mu \mathrm{M}\right)$ were maintained in continuous culture in human red blood cells $\left(\mathrm{A}^{+}\right)$diluted to 5\% haematocrit in RPMI 1640 medium supplemented with $25 \mathrm{mM}$ HEPES, $30 \mathrm{mM} \mathrm{NaHCO}$, and $10 \%$ human $\mathrm{A}^{+}$serum (Trager and Jensen, 1976).

The extracts were prepared as follows: $100 \mathrm{~g}$ of powder were extracted twice with equal volumes of petrol ether /ethyl acetate $(300 \mathrm{~mL})$ at room temperature<smiles>[R]c1cc(C2CC(=O)c3c(O)cc(OC4OC(C)C5O[C@H]4[C@@H]5O)cc3O2)ccc1O</smiles>

$1 \mathrm{R}=\mathrm{H}=5,7,4^{\prime}$-Trihydroxyflavanone-7-O- $\beta$-Dglucopyranoside $=$ Prunin $2 \mathrm{R}=\mathrm{OH}=5,7,3^{\circ}, 4^{4}-$ Tetrahydroxyflavanone-7-O- $\beta$-Dglucopyranoside $=$ Eriodictyol-7- $O-\beta$-D-glucopyranoside

Figure 1. Structures of flavanone glycosides isolated from M. foetida.

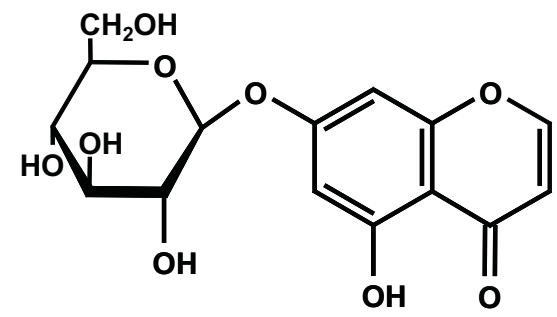

Figure 2. 5,7-Dihydroxychromone-7-

$O-\beta$-D-glucopyranoside (3). 
<smiles>O=c1c(O)c(-c2ccc(O)cc2)oc2cc(OC3OC(CO)C4OC3C(O)C4O)cc(O)c12</smiles>

Figure 3. Kaempferol-7- $O-\beta$-D-glucopyranoside $=$ Populnin (4).

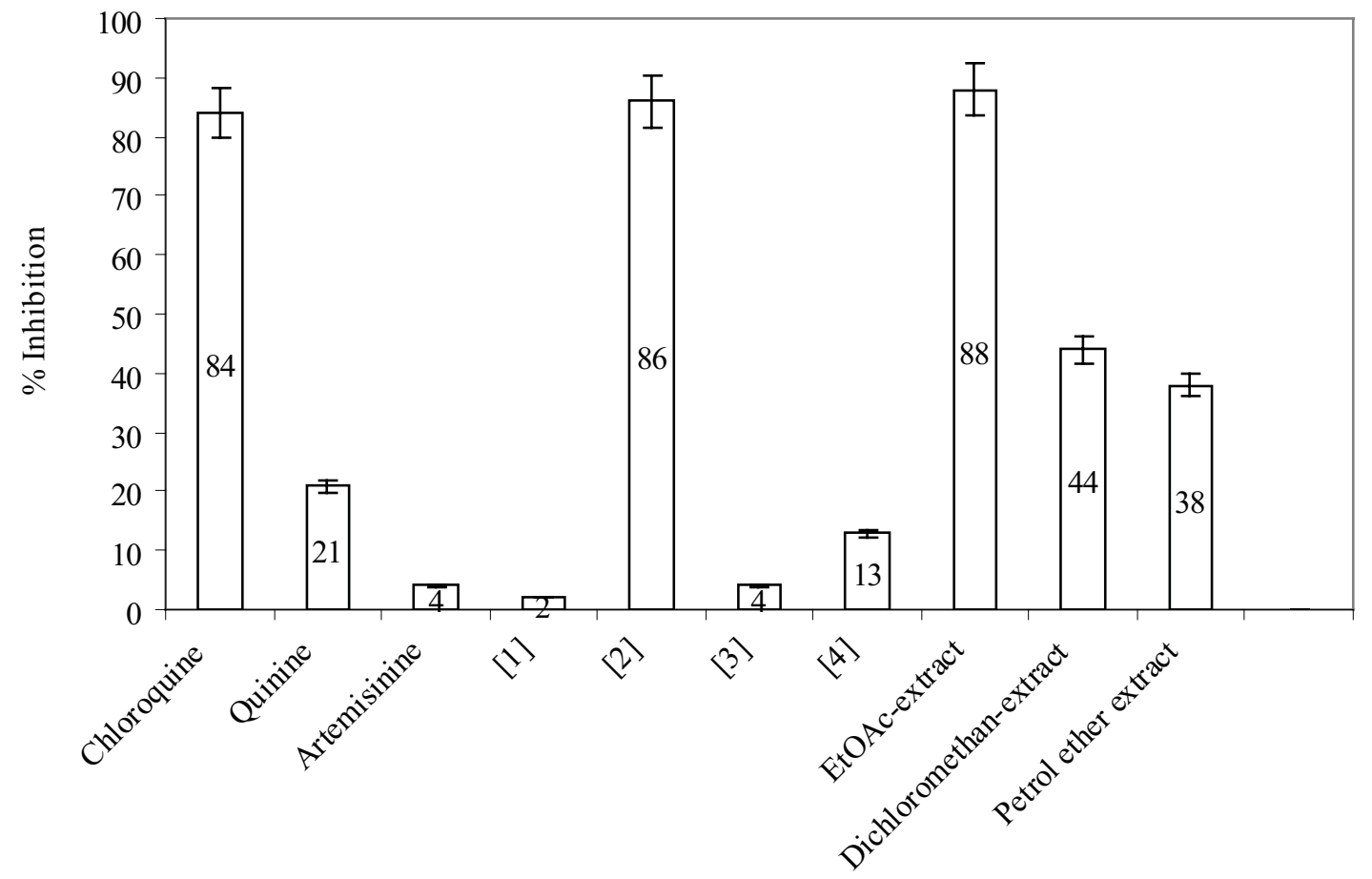

Figure 4. Inhibition of GSH-dependent haemin degradation (\%) of extracts $(100 \mu \mathrm{g} / \mathrm{mL})$ and compounds $(11 \mu \mathrm{M})$ obtained from M. foetida.

for 24 hours. Afterwards the plant powder was air dried and treated three times with $300 \mathrm{~mL}$ methanol. In either case, the solvents were evaporated from the combined solutions of each batch affording the corresponding crude drug extracts. The latter were dissolved in DMSO $(1 \mathrm{mg} / 50 \mu \mathrm{L})$ and diluted in RPMI 1640 medium. For determination of the $\mathrm{IC}_{50}$ values the samples were diluted to give final concentrations between 100 and $1.56 \mu \mathrm{g} /$ $\mathrm{mL}$.

Antiplasmodial activity tests were performed in 96-well culture plates (Corning ${ }^{\mathrm{TM}}$, Sigma Aldrich) as described by Desjardins et al. (1979). Briefly, aliquots of $150 \mu \mathrm{L}$ of parasitized culture $(2.5 \%$ haemocrit, $0.5 \%$ parasitaemia) were exposed to two-fold dilutions of test substances. After incubation in a candle jar for $24 \mathrm{~h}, 0.5$ $\mu \mathrm{Ci}$ of $\left[{ }^{3} \mathrm{H}\right]$ hypoxanthine $(1 \mathrm{mCi} / \mathrm{mL})$ was added to each well and the plates incubated for a further $18 \mathrm{~h}$.

Cells were harvested onto glass fibre filters (Wallac) with a cell harvester (Inotech) and incorporated radioactivity was determined by a liquid scintillation counter (1450 Microbeta plus). All tests were performed in triplicate. The percentage of growth inhibition was calculated as: [1-(cpm in drug treated cultures/cpm in untreated cultures)] x 100. The concentration at which growth was inhibited by $50 \%\left(\mathrm{IC}_{50}\right)$ was estimated by interpolation.

\section{Multiwell plate GSH-haemin interaction assay}

The GSH-haemin interaction assay was performed as described by Steele et al. (2002). In brief, three stock solutions were prepared: $1 \mathrm{mM}$ DETEPAC in 
Table 1. In vitro antiplasmodial activity of Momordica foetida leaf extracts on Plasmodium falciparum (poW- and Dd2-strain) and cytotoxicity on human cell lines ECV 304 and HepG2.

\begin{tabular}{|c|c|c|c|c|c|c|c|}
\hline Plant species & extract & $\begin{array}{c}\text { P. falciparum } \\
\mathrm{IC}_{50}(\mu \mathrm{g} / \mathrm{mL})\end{array}$ & $\begin{array}{l}\text { P. falciparum } \\
\mathrm{IC}_{50}(\mu \mathrm{g} / \mathrm{mL})\end{array}$ & $\begin{array}{c}\text { ECV-304 } \\
\mathrm{IC}_{50}(\mu \mathrm{g} / \mathrm{mL}) \\
\end{array}$ & $\begin{array}{c}\text { SI } \\
\text { ECV/Pf }^{\mathrm{a}} \\
\end{array}$ & $\begin{array}{c}\text { HepG2 } \\
\mathrm{IC}_{50}(\mu \mathrm{g} / \mathrm{mL})\end{array}$ & $\begin{array}{c}\text { SI } \\
\text { HepG2/Pf }{ }^{\text {a }} \\
\end{array}$ \\
\hline M. foetida & EtOAc/PE & 7.3 & 13.0 & 108.4 & 15 & 87.1 & 12 \\
\hline & $\mathrm{MeOH}$ & $>50$ & $>50$ & 141.8 & & 185.1 & \\
\hline
\end{tabular}

${ }^{\text {a }}$ poW-strain $=\mathrm{IC}_{50}$ value for chloroquine $=0.011 \mu \mathrm{M}$

${ }^{\mathrm{b}} \mathrm{Dd} 2$-strain $=\mathrm{IC}_{50}$ value for chloroquine $=0.12 \mu \mathrm{M}$

$10 \mathrm{mM}$ Na phosphate $\mathrm{pH} 7.0 ; 2 \mathrm{mM}$ haemin in DMSO (prepared fresh daily); $100 \mathrm{mM} \mathrm{GSH}, 1 \mathrm{mM}$ DETEPAC, $10 \mathrm{mM} \mathrm{Na}$ phosphate $\mathrm{pH}$ 6.8. For the experiments, working solutions were as follows: 'A', 4 vol. of DETEPAC/phosphate stock +1 vol. of ethanol; ' $\mathrm{B}$ ', $5 \mu \mathrm{L}$ of haemin stock solution per $\mathrm{mL}$ of solution ' $\mathrm{A}$ '; ' $\mathrm{C}$ ', 0.15 $\mathrm{mL}$ of GSH stock solution per $\mathrm{mL}$ of solution ' $\mathrm{A}$ '.

Assays were carried out in 96-well $(400 \mu \mathrm{L})$ flatbottomed plates. Solution A $(100 \mu \mathrm{L})$ was added, followed by drug ( $2 \mu \mathrm{L}$ of $2 \mathrm{mM}$ drug stock in DMSO) or solvent control in eight parallel samples. Solution B $(200 \mu \mathrm{L})$ was then added to all wells followed by $50 \mu \mathrm{L}$ of solution C. Final concentrations of drug, haemin and crude extract were $11 \mu \mathrm{M}, 5.7 \mu \mathrm{M}$ and $100 \mu \mathrm{g} / \mathrm{mL}$, respectively. The absorbance at $360 \mathrm{~nm}\left(A_{360}\right)$ was measured after 1 and 30 min with a plate reader Tecan Spectra Fluor to determine the $\Delta A_{360^{\circ}}$ The effect of the haemin-binding compounds was evaluated as the percentage decrease compared with control absorbance. Mean and SD for eight parallel samples of at least three independent experiments were calculated.

\section{Cytotoxicity}

Cytotoxicity of the extracts was estimated against human hepatocellar carcinoma (HepG2) and human urinary bladder carcinoma (ECV-304) (derivative of T-24) cells. Cytotoxicity was estimated by a proliferation assay using the MTT-assay (Mosmann, 1983; Freshney, 1990). Crude extracts were dissolved in DMSO and diluted with medium to the desired concentrations.

Human urinary bladder carcinoma cells (ECV304) were cultivated in Earle Medium 199 supplemented with $10 \%$ fetal calf serum in 96 well plates in an atmosphere of $5 \% \mathrm{CO}_{2}$ at $37^{\circ} \mathrm{C}$ in a humidified environment. The ECV-304 cells were seeded at a density of approximately 1000 cells per well. After $24 \mathrm{~h}$ they were supplemented with $100 \mu \mathrm{l}$ extract or substance in medium and cultivated for further 4 days. The cell viability was measured by the MTT-assay using DMSO to dissolve the formed purple formazan. The absorbance was quantified at $580 \mathrm{~nm}$ with a plate reader. Data are presented as the mean of 3 independent experiments with 8 parallel samples for each concentration. $\mathrm{The} \mathrm{IC}_{50}$ values were calculated by linear regression.
The human hepatocellar carcinoma (HepG2) cells were cultivated in MEM Earle medium supplemented with $10 \%$ fetal calf serum, $5 \mathrm{~mL}$ sodium pyruvate solution and $5 \mathrm{~mL}$ non-essential amino acids solution in 96 well plates in an atmosphere of $5 \% \mathrm{CO}_{2}$ at $37^{\circ} \mathrm{C}$ in a humidified environment. The HepG2 cells were seeded at a density of approximately 2000 cells per well.

\section{RESULTS AND DISCUSSION}

\section{Antiplasmodial activity and cytotoxicity of extracts}

In this study, we evaluated the in vitro antiplasmodial activity of hydrophilic and lipophilic extracts of $M$. foetida leaves against the chloroquinesensitive strain poW and the multiresistant clone $\mathrm{Dd} 2$ using an $\left[{ }^{3} \mathrm{H}\right]$ hypoxanthine-incorporation assay. The petrol ether/ ethyl acetate extract showed significant antimalarial activity with $\mathrm{IC}_{50}$ values of 7.3 (poW) and $13.0 \mu \mathrm{g} / \mathrm{mL}$ (Dd2).

Cytotoxicity of the extracts was estimated against human hepatocellar (HepG2) and human urinary bladder carcinoma (ECV-304, derivative of T-24) cells. Both extracts did not show pronounced toxicity $\left(\mathrm{IC}_{50}\right.$ values $>50 \mu \mathrm{g} / \mathrm{mL}$ ) and the selectivity indices (SI), defined as ratio of cytotoxic and antiplasmodial activity, which are presented in table 1, varied between 12 (HepG2) and 15 (ECV-304) (see table). These results might support the traditional use of $M$. foetida as antimalarial remedy.

\section{Phytochemical analysis}

The ethyl acetate soluble fraction was subjected to chromatography on Sephadex LH 20. Elution with methanol afforded compounds 1-4 (Fig. 1-3). Final purification was achieved by reverse phase HPLC and TLC. The compounds were identified as the known flavanone derivatives 5,7,4'-trihydroxyflavanone-7$O$ - $\beta$-D-glucopyranoside (1), also known as prunin, which was isolated before from the bark of Salix acutifolia Willd. (Zapesochnaya et al., 2002), 5,7,3',4'tetrahydroxyflavanone-7-O- $\beta$-D-glucopyranoside (Eriodictyol-7- $O-\beta$-D-glucopyranoside) (2) (Mun'im et al., 2003), the flavonole glycoside kaempferol-7- $O-\beta$-Dglucopyranoside (Populnin) (4) (Harbourne, 1994) and 5,7-dihydroxychromone-7- $O$ - $\beta$-D-glucopyranoside 
(Simon et al., 1994). None of these substances has been reported from $M$. foetida before.

Column chromatography of the dichloromethane extract of $M$. foetida leaves and further purification by TLC afforded 5 and $\mathbf{6}$. Compound 5 turned out to be 5,7dihydroxychromone, which is known, e. g. from Calluna vulgaris (Ericaceae) (Simon et al., 1994), but has never been detected before in the genus Momordica.

Compound 6 was identified as salicylic acid on the basis of its ${ }^{1} \mathrm{H}$ NMR and EI-MS spectra, a compound widespread in the plant kingdom (Hegnauer, 1964).

\section{Influence on GSH-dependent haemin degradation}

In order to check one possible antiplasmodial mode of action we evaluated the influence of the crude extracts of $M$. foetida as well as the isolated compounds on the glutathione-dependent heme degradation with chloroquine as reference compound.

When Plasmodium falciparum infects a human erythrocyte, it feeds on the degradation of hemoglobin. Hemoglobin is ingested from the host cell and is digested inside the parasites food vacuole. The by-product of this digestion is toxic heme or ferriprotoporphyrin, which is detoxified by forming an insoluble polymer, malaria pigment or hemozoin. Recently, an alternative heme detoxification mechanism has been described (Ginsburg et al., 1998).

Nonpolymerised heme exits the food vacuole into the parasites cytosol where it is degraded by glutathione. Quinoline antimalarials like chloroquine have been shown to interfere with both ways. Chloroquine accumulates to high levels inside the acid food vacuole where it complexes with heme and prevents its polymerisation. Free or complexed heme exits the food vacuole where its glutathione-dependent degradation is also inhibited. Heme thus accumulates in membranes and permeabilises them to cations, leading to parasite's death.

The reaction of hemin with glutathion and the interference of antimalarials can be monitored spectrophotometrically. The broad absorption of hemin is immediately changed to a peak at $364 \mathrm{~nm}$ upon addition of glutathione. During $30 \mathrm{~min}$ this peak decreases to approximately half without further decrease. Addition of quinoline antimalarials to hemin results first in the alteration of the hemin spectrum due to immediate formation of an alkaloid-hemin-complex and then leads to altered effects of glutathione. In the case of chloroquine the $364 \mathrm{~nm}$ peak is not formed and there is little change over $30 \mathrm{~min}$. These findings were used by Steele and co-workers to develop a microassay, which allows the identification of compounds that are able to inhibit the degradation of heme by GSH.

Among the crude extracts of $M$. foetida, only the ethyl acetate extract was able to interfere with haemin degradation, inhibiting it by $\sim 88 \%$ at $100 \mu \mathrm{g} /$
$\mathrm{mL}$ (Fig. 4). Compounds 1-4, which were obtained from this extract, were evaluated too. Eriodictyol-7-O- $\beta$-Dglucopyranoside (2) showed an inhibition of $86 \%$ similar to chloroquine with $84 \%$. Thus, a catechol sub-structure seems to be necessary for an interaction with haemin in this type of compounds. This is additionally stressed by the activity of quercetin in this assay (results not shown). Nevertheless, the antiplasmodial potency of $\mathbf{2}$ remains to be proven.

\section{ACKNOWLEDGEMENTS}

The authors are grateful to Mrs. U. Ostwald (Institut für Organische Chemie, FU Berlin) for providing the FAB-MS spectra. Thanks are due to Mrs. U. Friedrich for technical assistance in the cell laboratory.

\section{REFERENCES}

Desjardins RE, Canfield CJ, Haynes JD, Chulay JD 1979. Quantitative assessment of antimalarial activity by a semi-automated microdultion technique. Antimicrob Agents Chemother 16: 710-718.

Freshney RI 1990. Tierische Zellkulturen: Ein MethodenHandbuch 2. Auflage. Berlin, New York: De Gruyter p. 259-260.

Ginsburg H, Famin O, Zhang J, Krugliak M 1998. Inhibition of glutathione-dependent degradation of heme by chloroquine and amodiaquine as a possible basis for their antimalarial mode of action. Biochem Pharmacol 56: 1305-1313.

Hakizamungu E, Van Puyvelde L, Wery M 1992. Screening of Rwandese medicinal plants for anti-trichomonas activity. J Ethnopharmacol 36: 143-146.

Harbourne JB 1994. The Flavonoids. London, New York: Chapmann \& Hall.

Hegnauer R 1964. Chemotaxonomie der Pflanzen III. Basel und Stuttgart: Birkhäuser Verlag Vol. 3, p. 34-39.

Jeffrey C 1990. Cucurbitaceae in Flora of Tropical East Africa. London: Crown Agents.

Mosmann T 1983. Rapid colorimetric assay for cellular growth and survival: application to proliferation and cytotoxicity assays. J Immunol Methods 65: 55-63.

Mulholland DA, Sewram V, Osborne R, Pegel KH, Connolly JD 1997. Cucurbitane triterpenoids from the leaves of Momordica foetida. Phytochemistry 45: 391-395.

Mun'im A, Osamu N, Ozawa T 2003. Antioxidative compounds from Crotalaria sessiliflora. Biosci Biotechnol Biochem 67: 410-414.

Olaniyi AA 1975. A neutral constituent of Momordica foetida. $J$ Nat Prod 38: 361-362.

Olaniyi AA, Marquis VO 1975. Phytochemical and preliminary pharmacological investigation of the alkaloid obtained from Momordica foetida. Journal of Pharmacy (Yaba Nigeria) 6: 117-119.

Olaniyi AA 1980. 1 ß-Hydroxyfriedel-6(7)-ene-3-one from Momordica foetida. J Nat Prod 40: 303-305.

Rwangabo PC 1993. La medicine traditionnelle au Rwanda. Paris: Edition Karthala and ACCT.

Simon A, Chulia AJ, Kaouadji M, Delage C 1994. Quercetin3 -[Triacetylarabinosyl $(1 \rightarrow 6)$ galactoside] and 
chromones from Calluna vulgaris. Phytochemistry 36: 1043-1045.

Steele JCP, Phelps RJ, Simmonds MSJ, Warhurst DC, Meyer DJ 2002. Two novel assays for the detection of haemin-binding properties of antimalarials evaluated with compounds isolated from medicinal plants. $J$ Antimicrob Chemoth 50: 25-31.

Trager W, Jensen JB 1976. Human malaria parasites in continuous culture. Science 193: 673-675.

Waako PJ, Gumede B, Smith P, Folb PI 2005. The in vitro and in vivo antimalarial activity of Cardiospermum halicacabum L. and Momordica foetida Schumach. et Thonn. J Ethnopharmacol 99: 137-143.

Zapesochnaya GG, Kurkin VA, Braslavskii VB, Filatova NV 2002. Phenolic compounds of Salix acutifolia Bark. Chem Nat Compd 38: 314-318. 